\title{
Contingent Valuation Method and the beta model: an accounting economic vision for environmental damage in Atlântico Sul Shipyard*
}

\author{
Silvana Karina de Melo Travassos \\ Centro Universitário UNIFACISA, Departamento de Administração, Campina Grande, PB, Brazil \\ Email: silvanakmt@yahoo.com.br
}

\section{José Carlos de Lacerda Leite}

Universidade Federal da Paraíba, Centro de Ciências Exatas da Natureza, Departamento de Estatística, João Pessoa, PB, Brazil Email: carloslleite@gmail.com

\section{Jose Isidio de Freitas Costa}

Tribunal de Contas do Estado de Pernambuco, Assessoria de Pesquisa e Inteligência, Recife, PE, Brazil Email: jisidio@tce.pe.gov.br

Received on 12.14.2015 - Desk acceptance on 01.28.2016 - $4^{\text {th }}$ version approved on 04.11.2017 - Ahead of print on 02.19.2018

\begin{abstract}
The objective of this paper is to apply the beta model as an alternative to the Valuation Method in order to estimate the environmental asset Willingness to Pay (WTP) so that the Tribunal de Contas do Estado de Pernambuco (TCE/PE) can supervise the Atlântico Sul Shipyard (ASS) as a negative environmental externality, which is discussed here from an accounting perspective. Our methodology is exploratory, and the beta regression model was used in the contingent valuation to estimate the environmental asset. The results allowed estimating the value of the Ipojuca mangrove at US $\$ 134,079,793.50$, and the value of the environmental damage caused by the shipyard to the public asset was valued at US $\$ 61,378,155.37$. This latter value is object of interest to the inspection body. However, the final estimated value of the Ipojuca mangrove prompts a discussion about the implications from an accounting point of view, such as the attribution of monetary value to a public asset that does not have a financial value, problems regarding the conceptualization and valuation of public assets for governmental patrimony. It is concluded that the beta regression model to estimate the WTP for contingent valuation will serve as a contribution to the research on accounting measurement techniques for public assets.
\end{abstract}

Keywords: Contingent Valuation Method, beta model, environmental damage, accounting applied to the public sector.

Correspondence address

Silvana Karina de Melo Travassos

Centro Universitário UNIFACISA, Department Business and Administration

Av. Senador Argemiro de Figueiredo, 1901 - CEP 58411-020

Itararé - Campina Grande - PB - Brazil

*Paper presented at the XXXVI ENANPAD, Rio de Janeiro, RJ, Brazil, September 2012. 


\section{INTRODUCTION}

Mangroves are coastal ecosystems found in the tropics and subtropics of the Earth. Unique tree species grow on a silty substrate, whose influence over tides is remarkable and decisive for the survival and success of these plants, whose development has particular adaptations in an environment that would be rather stressful for other plant species (Odum, Mclvor, \& Smith, 1982; Tomlinson, 1986; Schaeffer-Novelli, 1995). Mangrove forests generally occupy coastal regions, but urbanization and other various activities in coastal cities and coastal states have produced severe socio-environmental impacts on coastal ecosystems (Scherer, Sanches, \& Negreiros, 2009).

Mangroves are among the most threatened environments on the planet, especially in the American and Asian continents (Valiela, Bowen, \& York, 2001). According to Schaeffer-Noveli (1989), mangroves are in the position of the most affected ecosystems among 30 others found on the Brazilian coast. However, the current Brazilian legal basis has no criteria for using the results of economic valuation for environmental damage. For this reason, this study was conducted to estimate the environmental damage related to suppression of mangrove vegetation, over the construction of Atlântico Sul Shipyard (ASS).

This situation requires research because fixing the damage value, although already regulated, is proposed in terms of a range between a minimum and a maximum value (Araújo, 2011). Therefore, the current legal basis, the Environmental Crimes Law, Law n. 9,605/98, does not explicitly presents a damage calculation parameter, which allows a subjective evaluation of the Court of Accounts and the Public Ministry, which currently set the values of fines and indemnities (Law n. 6,938/81 Federal Constitution 1988, Article 225).

In this study, the economic measurement of mangrove by Contingent Valuation Method (CVM) was chosen based on other previous studies (Diamond \& Hausman, 1994; Fischhoff \& Furby, 1988; Green, Jacowitz, Kahneman, \& McFadden, 1998; Hausman, 2012; Hammitt, Liu, \& Liu, 2001), and recently the research by Ferreira and Marques (2015). In addition, CVM is the most applied method by federal agencies with environmental responsibilities and international organizations (Leite, 2006).

In the recent international literature on CVM, the key word for econometric approaches in estimating the Willingness to Pay (WTP) is flexibility (Araña \& Lón, 2005; Cooper, 2003). For this reason, some studies were developed aiming at perfecting the modeling process by means of techniques that allow to capture the decisionmaking process of the individual. Haab and McConnel (1998) applied the beta distribution for modeling the WTP, but its use did not occur optimally since at the time there was no fully developed model that associated the mean response with the explanatory variables of the phenomenon being studied.

However, with the recent advances in statistical theory, Ferrari and Cribari-Neto (2004) proposed the beta regression model, which allows for a better use of the beta probability distribution, and this model was used in this study. Given the versatility of the regression model as an alternative to the CVM, it is possible to estimate the WTP for the mangrove preservation and to contribute to estimating the values of the asset and of the environmental damage. Therefore, the Tribunal de Contas do Estado de Pernambuco (TCE/PE) [Court of Accounts of the State of Pernambuco] may audit ASS by a negative externality, providing an accounting discussion of the case, regarding recognition and measurement of the environmental asset.

The objective of this paper is to apply the beta model as an alternative to the Valuation Method to estimate the WTP of the environmental asset so that the TCE/PE can oversee ASS as a negative environmental externality discussed from an accounting perspective.

The question investigated in this paper is structured as follows: Is there compliance with the application of beta model in estimating the WTP in relation to CVM to give subsidies to the inspection body regarding environmental damage and a way of incorporating accounting measurement?

This research is justified by valuing mangroves, since assigning a monetary value to public sector assets is one of the problems in the accounting measurement, i.e., to give a monetary value to assets and services related to the environment, which do not have an established or contracted value price (West \& Carnegie, 2010). However, accountants play an important role in the development of measurement techniques (Walker \& Llewellyn, 2002).

Nevertheless, accountants are still unfamiliar with the valuation methods (Sayce \& Connellan, 1998; Sayce, Britton, Morris, Sundberg, \& Watkin, 2009). Moreover, the techniques used to evaluate environmental resources and their values incorporated in the entities can have consequences, which in accounting can only be speculated (Stanton \& Stanton, 1997). In this accounting scenario, this research can be considered original due to the methodology with an econometric specification in using 
the beta regression model with the CVM to estimate the mangrove and the environmental damage values. Thus, contributing to the jurisdiction unit by providing subsidies to audit the external control regarding the environmental impact on the public patrimony.

This paper is divided into five sections, starting with this introduction; the next section presents the CVM and the contingent valuation using the beta regression model; the third section discusses the methodological approach used in this paper; the fourth section brings the analysis of the results; then the final considerations of this work.

\section{CONTINGENT VALUATION METHOD}

Regarding contingent valuation, Schweitzer (1990) considers it essential, since the degradation of the vast majority of natural resources is expected to be halted before it exceeds the limit of irreversibility.

In this sense, the valuation methods aim to supply the inexistence of markets and prices for the externalities of public assets constituted by natural resources (Guerra, Santos, Sanquetta, Bittencourt, \& Almeida, 2009). In order to fulfill this non-existence, the Economy of the Environment and Natural Resources classifies the techniques of valuing between direct and indirect, being the direct methods based on information from existing markets, and the indirect ones based on hypothetically created markets. As for the indirect methods, the CVM points out travel cost and substitute market or hedonic price (Guerra et al., 2009, Marques \& Comune, 1987).

The interview method consists in questioning the individual about his/her WTP for the use of the conservation of an asset or environment, or the Willingness to Accept (WTA) for the harm. WTP is estimated using open-ended elicitation questionnaires, referendum, payment cards and free throws (Dutta, Banerjee, \& Husain, 2007; Marques \& Freire, 2015; Motta, 1997). For this study, we used an open-ended elicitation as a way to obtain it, in which the questionnaire presents the following question: "How much are you willing to pay"? (Motta, 1997). In the CVM, the questions are formulated in the questionnaire in a clear and concrete way, in order to avoid evasive or doubtful answers, or the non-response (Benakouche \& Cruz, 1994; Guerra et al., 2009).

CVM aims to establish a hypothetical market so that environmental resource users show, depending on his/her preferences and socioeconomic profile, his/ her WTP/WTA by changes in the quantity and quality of environmental resources. This method differs from others because of the possibility to capture the value of the existing natural resources. Therefore, this is the great advantage of the CVM: being able to capture the value of use and non-use of an asset, even if there is no market
(Blakemore \& Williams, 2008; Motta, 1997; Travassos, 2012).

The method has a high theoretical validity, but it does not have a high market validity because it uses a market simulation model (Porter, 2004). The main limitation of CVM is capturing environmental values that individuals do not understand or do not know. Another limitation concerns the method biases that affect the reliability of the results, which should be minimized with the planning of the questionnaire, the sample and the appropriate structuring of its application (Willis, 1995).

In addition, another limitation of the method is the fact that individuals who may be willing to pay a stated amount for a particular asset but would not express the same value because of constraints in their budget, if they were asked to pay for a larger set of environmental benefits (Motta, 1997).

Another limitation of this method is the application of questionnaires that give estimative biases that affect reliability regarding strategy, hypothetical markets, partwhole, information, interviewee and interviewer, payment vehicle, point or anchoring, obedience, subactivity, and aggregation (Wills, 1995; Wakim, Magalhães, Diane, Silva, \& Pereira, 2013).

However, considering the recommendations of the National Oceanic and Atmospheric Administration (NOAA) panel, the surveys to be used in a CVM research should include a range of issues not only related to socioeconomic factors (income, age, education level), as well as alternatives that support the interpretation of WTP values, like social and environmental variables. These variables should express the behavior and the ecological point of view of users in relation to the environmental asset (Arrow, Solow, Portney, Leamer, Radner, \& Shuman, 1993). In addition to the caution regarding the research planning, the criteria established by NOAA $(1983,1984)$ help maximize the credibility and reliability of the CVM in the polls. 


\subsection{Contingent Valuation through the Beta Regression Model}

Using CVM to obtain the WTP is very frequent since it was formalized by Hanemann (1984), who uses the referendum model in conjunction with econometric modeling based on logistic regression. From that work, several econometric models have been proposed in the literature to estimate the WTP, among these, probit and logit were the most traditional models. However, traditional parametric models fail to represent the empirical data distribution, leading to specification errors bias and inconsistent results with microeconomic theory, for example, a negative WTP.

The idea of using the beta regression model with CVM is precisely to use the versatility of the beta distribution to model a variety of uncertainties, so that a more flexible model allows a better grasp of the "nuances" of the sample data, obtaining an improved estimative of WTP. The model was used for the first time as an alternative econometric approach in the CVM in Leite (2006) and posteriorly Travassos (2012) aiming to obtain better adjustments to the sample data and, therefore, a more improved estimative of the maximum WTP, in addition to meet the minimum criteria necessary to estimate the WTP.

The use of the beta model with the CVM is defined from a continuous response variable in the interval $(0 ; 1)$ that represents the proportion of income that the individual is willing to spend with the public or environmental asset. This ratio can be defined either by the referendum approach, using the offered bid quotient/income, as well as by open questions, using the maximum WTP of the individual for the asset in the quotient numerator.

Ferrari and Cribari-Neto (2004) proposed a regression model for continuous variables that assume values in the unit interval $(0 ; 1)$ and its response variable follows the beta distribution. In the beta model applied to the $\mathrm{CVM}$, it is assumed that the response variable represents the WTP/income ratio that follows the beta probability distribution with parameters represented by the mean $\mu$ and the precision $\varphi$. In addition, the regression parameters are interpretable in terms of the mean of the variable of interest, the model is naturally heteroscedastic and its flexibility accommodates several forms of asymmetries.

The model beta proposed by Ferrari and Cribari-Neto (2004) circumvents the previous difficulties of other beta models to relate the mean response variable with beta probability distribution parameters and with the predictors in the model through a function of reparameterization of beta density, in which $\mathrm{E}(\mathrm{y})=\mu=\mathrm{p} /(\mathrm{p}+\mathrm{q}), \varphi=\mathrm{p}+\mathrm{q}$ and $\operatorname{VAR}(\mathrm{Y})=\mu(1-\mu) /(1+\varphi)$. Thus, the beta density is defined as a function of the mean $\mu$ and the precision parameter $\varphi$ as shown below:

$$
f(y ; \mu, \phi)=\frac{\Gamma(\phi)}{\Gamma(\mu \phi) \Gamma((1-\mu) \phi)} y^{\mu \phi-1}(1-y)^{(1-\mu) \phi-1}, 0<y<1
$$

where $\Gamma(\mathrm{p})$ is the gamma function evaluated at point $\mathrm{p}, 0<$ $\mu<1$ and $\phi>0$. An interesting observation regarding the beta model is that the variance of the ratio $y$ is a function of its mean $\mu$, and, as a consequence of the model, function of the values of the explanatory variables. Therefore, variable responses of non-constant variances are naturally accommodated in the model, being able to model variables with different forms of heteroscedasticity, such as the $\mathrm{WTP} /$ income ratio.

The main reason for the use of beta regression is the flexibility assumed by the beta probability distribution, whose density can present several formats, as it can be observed in Figure 1, which presents different densities of the beta type for different levels of the parameters $\mu$ and $\varphi$.
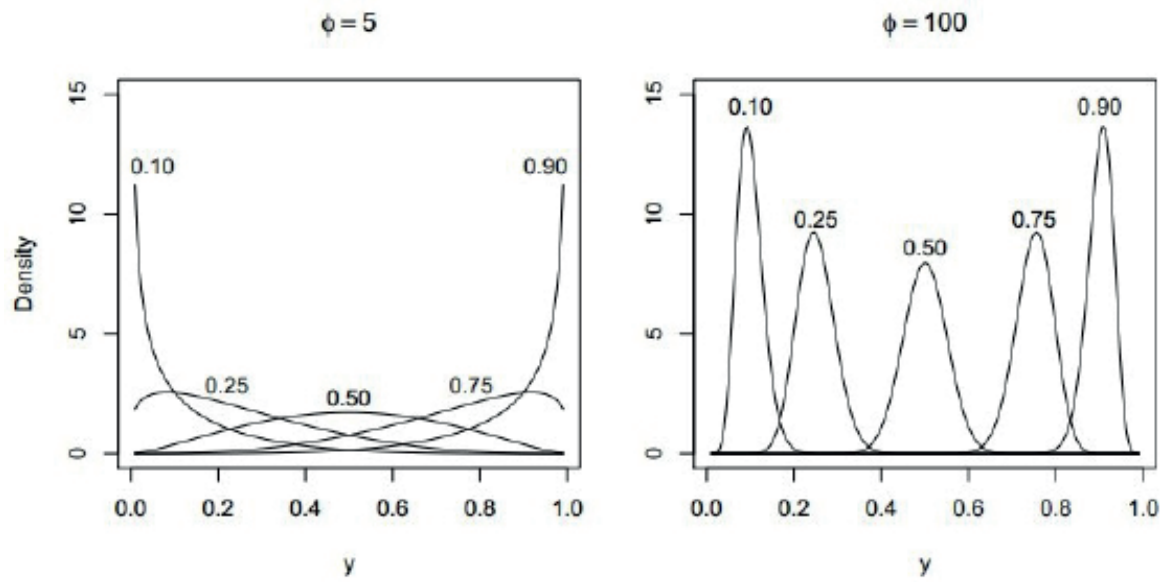

Figure 1 Beta distributions with mean $(\mu=0.10,0.25,0.50,0.75,0.90)$ and accuracy parameters $\varphi=5$ left and $\varphi=100$ right Source: Cribari-Neto e Zeileis (2010). 
The beta regression model is defined by $\mathrm{g}\left(\mu_{t}\right)=\sum_{i=1}^{k} x_{t i} \beta_{i}=\eta_{t}, i=1, \ldots, \kappa$ and $t=1, \ldots, \mathrm{b}$, in which $\beta=\left(\beta_{1}^{i=1}, \ldots, \beta_{k}\right)^{T}$ is a vector of unknown parameters to be estimated, $x_{t}^{T}=\left(x_{t 1}, \ldots, x_{t k}\right)$ represents the values of k explanatory variables that are assumed fixed and unknown. The model is similar to generalized linear models and uses a strictly monotonous and doubly differentiable general binding function, $\mathrm{g}($.), with the aim of linearizing the relationship between the mean of the response variable and the predictors. The most usual connection functions are logit, probit, identity and loglog complement.

The model parameters are estimated using the maximum likelihood method and do not have a closed form, and it is necessary to use iterative methods. Using asymptotic theory, Ferrari and Cribari-Neto (2004) developed hypothesis tests based on the likelihood ratio tests and confidence intervals to assess the modelfitting adequacy. Among the diagnostic techniques of the model, the authors proposed three global measures of fit quality of the model: (i) The "pseudo" $\mathrm{R}^{2}$ is defined as the square of the sample correlation coefficient between $\mathrm{g}(\mathrm{y})$ and the predictor $\hat{\eta}$. Note that $0<\mathrm{R}^{2}<$ 1 and the closer to 1 is its value, the better is the fit; (ii) The second measure is based on a likelihood ratio between the null model (without covariates) and the model under study; (iii) The third measure is based on ordinary residues or its standardized variants and/ or residual deviance. This measure evaluates that the discrepancy of an adjustment can be measured as twice the difference between the maximum log of the likelihood of the saturated model and the model under study.

The reparametrized beta model has undergone some improvements, among which we can mention the studies of Simas, Barreto-Souza and Rocha (2010), which proposed a variant of the beta regression model that allows non-linearity and the parameter of precision $\varphi$ variable; and Ospina and Ferrari (2012), who proposed the inflated beta regression model of zeros or ones. These studies may be particularly useful for estimating the WTP, which are generally derived from data inflated with zeros.

By using the referendum approach, consumer preferences are revealed when the respondent says yes or no to the bid amount offered for the asset. The WTP can be estimated as $d=\gamma i$.yi, where $\gamma$ i represents the income ratio of the $\mathrm{i}$-th individual and yi is its respective income, so that the WTP expectation is given by the product between the estimated proportion and income. As the proportion is defined as a function of a set of explanatory variables, then we can expect the proportion of income to differ for each individual in the sample according to their particular characteristics. Therefore, this model does not present the restrictive assumption that the proportion of income is constant, as this would cause problems for assets that have an increasing proportion regarding the income.

Thus, the beta model represents a viable parametric approach with the advantages of the parametric approach added by the flexibility of its distribution. It has an economic interpretation similar to Hanemann's referendum approach $(1984,1989)$ and allows WTP estimation to be consistent with the minimum criteria defined by Haab and McConnell (1998), in the estimation and calculation stages of WTP.

\section{METHODOLOGICAL PROCEDURE}

The sampling plan for the valuation of the mangrove was established considering that the interviewees were randomly chosen, in the municipalities of Ipojuca and Cabo de Santo Agostinho, located on the southern coast of Pernambuco, where the questionnaires were applied. A pilot study was carried out to determine the sample size needed to estimate the preference of the interviewee for the mangrove preservation, considering the sample unit as the number of households in the municipalities, at $95 \%$ confidence level and with a maximum permissible error of 0.033 . A minimum sample size of 874 observations was obtained. In the total, 1,065 questionnaires were applied following the NOAA recommendations and, after an analysis for the exclusion of missing values, possible outliers, and analysis of the answers that presented inconsistencies, 907 questionnaires were used for econometric modeling. The selected sample presented a reasonable size for the implementation of the technique; however, there was no proportionality in the application of the questionnaires in relation to the population of each region.

The calculation of the estimated values for the mangrove follows the methodology adopted in the studies carried out by Leite (2006), Martins and Melo (2007) and Travassos (2012). The beta regression model, with probit link function and log-log complement, was used to estimate the mean WTP ratio (WTP $\mu$ ) per household in mangrove preservation (see section 4).

An inevitable limitation is the transposition of data referring to Maracaípe mangrove to Ipojuca mangrove since the latter was destroyed to construct ASS. Given the fact that the destruction of Ipojuca mangrove had occurred, 
its value was obtained in this study by transferring from the estimated value of the Maracaípe mangrove. In this sense, with the parameterization to Ipojuca mangrove, it was possible to calculate the environmental damage (see section 4).

Microsoft Office Excel 2007 was used as a computational support for data tabulation and for creating dummies. The estimation of the proposed models was performed in R-2.12.0 available at http://www.r-project.org. Beta regression was implemented through the betareg package.

The values presented in the survey at the date of applied quotation were of the last business day of the month (June 2011), where the conversion of the buying and selling currency was: $1 \mathrm{real} / \mathrm{Brazil}=\mathrm{US} \$ 0.640574$ (USA dollar); US\$ $1=$ US\$ 1.5610999 real/Brazil (BCB, 2017).
The interviewees were randomly selected, and after the consolidation of the sample data, an observation of the socio-demographic variables resulting from the collection was made. Descriptive measures of the variables related to educational level, the area of residence, gender, and monthly family income were analyzed. Regarding gender, $39 \%$ of the sample is made up of women. Regarding education, $29.1 \%$ had primary education, $55.7 \%$ had secondary education and $15.2 \%$ had higher education, which was significant in the model.

In Table 1, the data presented the following configuration according to the family income, educational level of the population, the decision on mangrove preservation and its functions, and WTP.

Table 1

Descriptive measures of variables

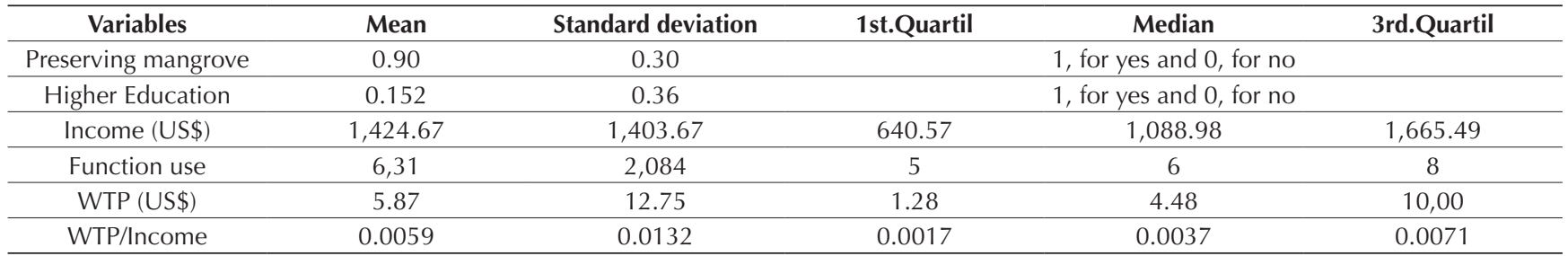

Note: The mangrove function variable refers to the individual's knowledge about the functions of the mangrove among the nine functions presented and assumes a value from 0 to 9, related to the supply of wood, food source, medicines, retention of excess water, shoreline protection, biodiversity maintenance, erosion control, nutrient recycling, and temperature stabilization.

Source: Developed by the authors

It can be observed that the average income of the interviewees was US\$1,424.67. In addition, they showed a good knowledge about the functions of the mangrove, since $90 \%$ are favorable to its preservation and showed an average WTP of US\$ 5.87. The median value was US\$ 4.48 , confirming the WTP asymmetry.

After the description of the data, a parameter estimation was performed through the beta regression, whose results are analyzed in the following section. From the models, it is calculated the total value of Maracaípe mangrove and the damage estimated for ASS, by negative externalities in Ipojuca mangrove. The results prompt a discussion about problems from an accounting point of view regarding the attribution of monetary value to the public asset that does not have a financial value. For a better understanding of the phenomena here presented, this paper is characterized by a bibliographical and exploratory research (Malhotra, 2001; Cooper \& Schindler, 2003).

\section{ANALYSIS OF RESULTS}

\subsection{Beta Models with Probit Link Functions and Log-Log Complement}

Beta models were adjusted to estimate the WTP/ income ratio with different link functions to verify the suitability of the model to the sample data. The purpose of the link function is to linearize the relationship between the mean response and the predictors, choosing the link function that provides greater $\emptyset$ and pseudo $\mathrm{R}^{2}$, which are indicators of the probability that the model is welladjusted to the data. The models with probit and log-log complement link function were the ones that presented greater data adequacy.

The probit link function is similar to the logit model, in which the link function is the probit function, defined as Probit $g(\mu)=\emptyset^{-1}(\mu)$ in which $\Phi($. $)$ is the standard normal 
distribution function, which estimates the probability of accepting and rejecting payment of the amount offered. The log-log complement link function is defined as $g(\mu)=\log [-\log (1-\mu)]$, which assumes non-negative values for $\mu>0$ and, then, it can be used by admitting that WTP $\mu$ does not assume negative values. Table 2 presents the results of the estimates of the beta regression model, with log-log and probit complement link functions.

Table 2

Estimated beta regression models

\begin{tabular}{|c|c|c|c|c|c|c|}
\hline \multirow[t]{2}{*}{ Variables } & \multicolumn{3}{|c|}{ Log-log Complement Link Function } & \multicolumn{3}{|c|}{ Probit Link Function } \\
\hline & Estimate & $Z$ value & $\operatorname{Pr}(>|z|)$ & Estimate & $Z$ value & $\operatorname{Pr}(>|z|)$ \\
\hline Intercept & -2.0763744 & -79.671 & $<2 \mathrm{e}-16^{* * *}$ & -3.420588 & -67.987 & $<2 \mathrm{e}-16^{* * *}$ \\
\hline High income & -0.2015431 & -19.030 & $<2 \mathrm{e}-16^{* * *}$ & -0.393578 & -20.504 & $<2 \mathrm{e}-16^{* * *}$ \\
\hline Average income & -0.1000751 & -10.406 & $<2 \mathrm{e}-16^{* * *}$ & -0.199693 & -11.800 & $<2 \mathrm{e}-16^{* * *}$ \\
\hline Educational level (1) & 0.0137778 & 0.612 & 0.5408 & 0.018058 & 0.444 & 0.6572 \\
\hline Educational level (2) & -0.0049109 & -0.220 & 0.8257 & -0.022954 & -0.570 & 0.5683 \\
\hline Educational level (3) & -0.0556123 & -2.258 & $0.0239 *$ & -0.110803 & -2.495 & $0.0126 *$ \\
\hline Function use & -0.0005766 & -0.317 & 0.7514 & -0.001045 & -0.326 & 0.7442 \\
\hline Preserve or not & 0.1635861 & 10.387 & $<2 \mathrm{e}-16^{* * *}$ & 0.353343 & 10.238 & $<2 \mathrm{e}-16^{* * *}$ \\
\hline WTP > US\$12.81 & 0.6069849 & 39.598 & $<2 \mathrm{e}-16^{* * *}$ & 1.165089 & 39.879 & $<2 \mathrm{e}-16^{* * *}$ \\
\hline WTP US\$9.61-12.81 & 0.5123948 & 31.141 & $<2 \mathrm{e}-16^{* * *}$ & 0.999768 & 32.032 & $<2 \mathrm{e}-16^{* * *}$ \\
\hline WTP US\$6,41-9.61 & 0.4428494 & 33.039 & $<2 \mathrm{e}-16^{* * *}$ & 0.867464 & 32.445 & $<2 \mathrm{e}-16^{* * *}$ \\
\hline WTP US\$3.20-6.41 & 0.3504325 & 27.342 & $<2 \mathrm{e}-16^{* * *}$ & 0.696482 & 26.806 & $<2 \mathrm{e}-16^{* * *}$ \\
\hline Parameter & 381.11 & 18.49 & $<2 \mathrm{e}-16^{* * *}$ & 408.9 & 18.50 & $<2 \mathrm{e}-16^{* * *}$ \\
\hline Pseudo $\mathrm{R}^{2}$ & 0.6859 & \multicolumn{2}{|c|}{ Error: 2.06} & 0.6476 & \multicolumn{2}{|c|}{ Error: 2.21} \\
\hline Maximum likelihood & \multicolumn{3}{|c|}{$\mathbf{5 3 7 0}$ with 13 degrees of freedom } & \multicolumn{3}{|c|}{$\mathbf{5 3 9 5}$ with 13 degrees of freedom } \\
\hline
\end{tabular}

Note: Codes of significance levels of the tests: * significant at $p<10 \%$; ${ }^{* *}$ significant at $p<5 \%$; ${ }^{* *}$ significant at $p<1 \%$.

Source: Developed by the authors.

The criteria for choosing the model were based on the precision parameter $\emptyset$, pseudo $\mathrm{R}^{2}$, and log likelihood. The models were reasonably well adjusted to the data. For the $\log$-log model, the pseudo $\mathrm{R}^{2}$ of the estimated regression is $68.59 \%$, indicating a good fit to the model. The estimated precision parameter $\emptyset$ was equal to 38.11 with a standard error of 2.06. The log likelihood was 5370 with 13 degrees of freedom, accepting the hypothesis of the adequacy of the model for this study. For the Probit model, the pseudo $\mathrm{R}^{2}$ of the estimated regression is $64.76 \%$, indicating a good fit to the model. The estimated precision parameter $\emptyset$ is equal to 40.89 with a standard error of 2.21. The log likelihood statistic was 5395 with 13 degrees of freedom.

Regarding the analysis of the parameters of the model based on the economic literature on contingent valuation, normally it is expected that the signs of the model parameters by using the logistic regression model are as follows: the higher the variables education, income, and knowledge of the functions of the mangrove, the greater will be the willingness to contribute to its preservation of the mangrove. However, for the beta model, the answer is the WTP/income ratio, and it is expected that the higher the income and education, the lower the proportion, therefore a negative sign relation is expected in these cases. However, when estimating WTP by the product between the estimated proportion and the income, the tendency of a higher WTP for individuals with higher income is verified.

Moreover, income as a predictor of the model can be categorized in order to avoid possible problems of multicollinearity that can occur with the response variable and with education. Other alternatives to address the possibility of multicollinearity are applying the logarithmic transformation in income, categorizing the education variable or isolating the effects of income, education, and interaction education-income through multivariate techniques. The categorized income presented negative estimated parameters and the magnitude was consistent with the theory so that larger incomes showed a greater reduction in the $\mathrm{WTP} /$ income ratio.

The estimated parameters of the categorized income variable reveal a behavior in which the WTP value appears to be stationary, indicating that the population assigns an approximately constant level of value to the mangrove, and there is no significant change in case of increase or decrease in income. Although higher incomes are 
associated with higher WTP values, however, the increase in WTP is not directly proportional to the increase in income, so there is some stability in the WTP values.

The middle and upper-income groups, with higher purchasing power due to their incomes, showed negative signs, which is a smaller allocation of the proportion of their incomes.

The two models presented the estimated values of compliance with economic theory since the consumer is willing to pay only a small portion of his income, as expected, with no negative value as it occurs in some circumstances, when inadequate models are used. In addition, multiplying the estimated values by the income of the individual results in the estimated values of the WTP, and it is observed that all values are non-negative. Haab and McConnell (1998), Leite (2006) and Travassos (2012) defend the minimum criteria for the validation models for WTP since they consider that the WTP of each individual is a non-negative value and is limited superiorly by income.

The modification in the econometric approach to estimate the WTP using the beta model instead of the logit model has the advantage of estimating the average proportion of the income that the respondent accepts to pay directly for the existence of the asset. In the logit model, the estimate was made from the estimation of the probability of accepting or rejecting the value offered in the interviews. The use of beta regression as an alternative for econometric modeling of the CVM, besides meeting the minimum criteria for estimation of the WTP, incorporates several benefits such as the flexibility of the beta distribution in modeling a variety of uncertainties and correcting a possible heteroscedasticity when adapting the inherent characteristics of income data and WTP.

Table 3 shows the estimated results in the models of beta regression with log-log and probit complement link functions, their respective minimum and maximum values, median and mean, first and third quartile. These data are available in dollar currency (US\$) and in the value of the proportion of income (\%) referring to WTP $\mu$ monthly of the households in Ipojuca (I) and Cabo de Santo Agostinho (CSA), with active average income of US\$ 248.25 (I) and US\$277.84 (CSA).

Table 3

Summary of the results of WTP per household and their estimated proportions with log-log and probit complement link function

\begin{tabular}{cccccccc}
\hline \multirow{3}{*}{ Log-Log } & Min. & $\mathbf{1 s t}$ Qu. & Median & Mean & 3rd Qu. & Max. \\
\cline { 2 - 7 } & $\mathbf{( U S \$ )}$ & $\mathbf{0 . 6 1}$ & 3.81 & $\mathbf{6 . 4 7}$ & 8.47 & 9.90 & $\mathbf{1 1 4 . 2 5}$ \\
\cline { 2 - 7 } & $\mathbf{( \% )}$ & $\mathbf{3 . 1 6 1 e - 0 5}$ & $1.228 \mathrm{e}-03$ & $\mathbf{4 . 9 2 5 e - 0 3}$ & $5.946 \mathrm{e}-03$ & $8.340 \mathrm{e}-03$ & $\mathbf{2 . 6 1 9 e - 0 2}$ \\
\hline \multirow{2}{*}{ Probit link } & $\mathbf{( U S \$ )}$ & $\mathbf{0 . 6 1}$ & 3.81 & $\mathbf{6 . 4 9}$ & 8.49 & 9.92 & $\mathbf{1 1 4 . 5 2}$ \\
\cline { 2 - 7 } & $\mathbf{( \% )}$ & $\mathbf{4 . 1 8 9 e - 0 5}$ & $1.124 \mathrm{e}-03$ & $\mathbf{4 . 6 8 0 e - 0 3}$ & $5.959 \mathrm{e}-03$ & $8.257 \mathrm{e}-03$ & $\mathbf{2 . 9 7 1 e - 0 2}$ \\
\hline
\end{tabular}

Note: The Central Bank of Brazil's currency converter uses the most significant digits of the cents for conversion, not considering cents of currency (BCB, 2017).

Source: Developed by the authors.

It can be observed that the predicted WTP values for both models are similar. The proportions of the average incomes resulted in 0.005946 (log-log complement), which is equivalent to a WTP $\mu$ for households of US $\$ 8.47$, and in 0.005959 (probit link) that provides a monthly WTP of US $\$ 8.49$. The results of contingent valuation by beta modeling to estimate the $\mathrm{WTP} \mu$ contribute to expressing the importance of the mangrove and the consequence of its preservation.

\subsection{Estimation of Values of WTP, Environmental Asset and Environmental Damage}

In order to estimate the monthly disposition $\left(\mathrm{WTP}_{\mu / \text { month }}\right)$ by domicile of the municipality of Ipojuca and Cabo de Santo Agostinho, the monthly average nominal per capita income of the population was used for the respective municipalities, and these data are available in the Banco de Dados do Estado de Pernambuco (BDE/PE, 2010) [Database of the State of Pernambuco]. The value of the average income of the population was multiplied by the value of the proportion of the average income (log-log complement), considering the bids up to US\$ 16.01. It was then multiplied by the number of households registered in the 2010 demographic census, made available by the Instituto Brasileiro de Geografia e Estatística (IBGE, 2010) [Brazilian Institute of Geography and Statistics] for the municipalities of Ipojuca and Cabo de Santo Agostinho. 
Table 4

Estimated WTP values in the municipalities

\begin{tabular}{lcc}
\hline \multicolumn{1}{c}{ Parameter } & \multicolumn{2}{c}{ Municipalities } \\
\cline { 2 - 3 } & Ipojuca & Cabo de Santo Agostinho \\
\hline Nominal average monthly income per capita & US\$248.25 & US\$ 277.84 \\
\hline Proportion of average income & 0.005946 & 0.005946 \\
\hline Households & 29.018 & 64.485 \\
\hline Total monthly WTP & US\$ 42,833.31 & US\$ 106,531.58 \\
\hline
\end{tabular}

Note: $W T P=R_{\mu p} \times R P_{R B \log -\log } \times D$ where, $R_{\mu p}$ is the amount of the nominal monthly average income per capita, $R P R_{B l o g-l o g}$ is the proportion of income and $D$ households. Household data are available at IBGE of 2010.

Source: Developed by the authors.

For the valuation of environmental asset of Maracaípe mangrove, the value of the $\mathrm{WTP}_{\mu / \text { month }}$ of the municipality of Ipojuca was calculated and was similarly applied to the municipality of Cabo de Santo Agostinho. Thus, this amount was divided by the interest rate, the Taxa Referencial (TR) [Reference Rate] of June 2011, for the calculation of perpetual income in the respective municipalities.

The choice for the TR occurred because it offers lower rates in the financial market (0.001114 Jun/2011). Its calculation is based on a sample composed of the 20 largest references of financial institutions of the country, thus considered according to the volume of funding made through $\mathrm{CDB} / \mathrm{RDB}$ certificates, with a term of 30 to 35 consecutive days, and remunerated to prefixed rates between multiple banks, commercial banks, investment banks and savings banks (BCB, 2017).

In addition, this choice was based on recommendations of the authors (Motta, 1997; Solow, 1974), in which a very high rate implies a large reduction in the current value that would lead the value of the environmental asset to be reduced in the future. The result would be a decision for immediate use of the property or natural resource, and not for its preservation for posterity.

The method used as a composition for calculating the environmental asset was aperpetual income, which was applied in studies by Armas (1981), Instituto Nacional de Planificación, Tomo I, (1980) and Morehouse (1935). It considers the land as an asset and it has derived value of its future income, considering its value as perpetuity. In this study, mangrove is a capital asset and the mangrove value is a perpetuity. Perpetual income is defined as income whose payments are infinite (or, in practical cases, it is very large).

In this case, there is only interest in determining the relationship between the present value of income and the associated periodic income. For immediate floating rate income, the present value can be mathematically determined when " $n$ " tends to infinity (Mathias \& Gomes, 2008).

Table 5

Estimated Environmental Asset Value

\begin{tabular}{lcc}
\hline \multicolumn{1}{c}{ Parameter } & \multicolumn{2}{c}{ Municipalities } \\
\cline { 2 - 3 } & Ipojuca & Cabo de Santo Agostinho \\
\hline Total monthly WTP & US\$ 42,833.31 & US\$ 106,531.58 \\
\hline Reference Rate & 0,001114 & 0,001114 \\
\hline Total estimated value of environmental asset per municipality & US\$ 38,450,008.98 & US\$ 95,629,784.56 \\
\hline Value of Total Environmental Asset & \multicolumn{2}{c}{ US\$ 134,079,793.50 } \\
\hline
\end{tabular}

Note: $V_{a}=\frac{W T P}{i}$ where $V_{a}$ is the estimated value of the environmental asset by each municipality and $i$ is the Reference Rate (Taxa Referencial - TR). TR rate of June (2011). Vtea is the Value of Total Environmental Asset = US\$38,450,008.98+ US\$ 95,629,784.56.

Source: Developed by the authors. 
In order to calculate the environmental damage, considered as a negative externality, it was applied the Vtea, dividing by the total area of Maracaípe mangrove per square meter, and multiplying by the square meter suppressed by ASS of Ipojuca mangrove. The total area of Maracaípe mangrove was used in Geographic Information System (GIS) from data provided by the Agência Estadual de Meio Ambiente (CPRH, 2010) [State Agency for the Environment]. The total area of Maracaípe mangrove is 170.39 ha, according to information obtained from the Engineering Center of TCE/PE.

$$
\text { DAMAGE }=\frac{\text { Vtea }}{a_{t}} \cdot a_{s}=\text { US } \$ 61,378,155 \cdot 37
$$

in which Vtea is the value of Total Environmental Asset = US $\$ 134,079,793.50$; is the total area per $\mathrm{m}^{2}$ of Maracaípe mangrove $=1,703,900 \mathrm{~m}^{2} ; \mathrm{a}_{\mathrm{s}}$ is the suppressed area $\mathrm{m}^{2}$ of Ipojuca mangrove $=780,000 \mathrm{~m}^{2}$.

Thus, the value of environmental economic damage estimated by contingent valuation was US $\$ 61,378,155.37$ for the Ipojuca mangrove destruction because of the implementation of ASS, object of interest to TCE/PE. To find the value of $\mathrm{m}^{2}$ suppressed from Ipojuca mangrove, the amount of estimated damage was divided by $\mathrm{m}^{2}$ suppressed. $\mathrm{Vm}^{2}=\mathrm{US} \$ 61,378,155.30 / 780,000$ the value of $\mathrm{m}^{2}$ suppressed by ASS was estimated at US\$ 78.69.

In this case, the estimated value of the damage as suggested subsidy to the ASS surveillance by negative externality caused to natural resources was presented to TCE/PE. This practice of valuation has been adopted since 1990 by the U.S. legal system, which makes use of the valuation results to establish compensation (Carlo, 1999; Serra, Garcia, Ortiz, Hasenclever, \& Moraes, 2004). On the other hand, the final estimated value of Maracaípe mangrove and the damage estimated by ASS due to negative externalities in Ipojuca mangrove prompt a discussion. Both in the Comitê de Pronunciamentos Contábeis (CPC) [Committee on Accounting Pronouncements] and in the International Public Sector Accounting Standard (IPSAS), accounting accepts the estimated value, for example, for fair value measurements (CPC 46), intangible assets (CPC 04 R1), the Financial Instrument (CPC 38) and the accounting policies, changes in estimates and error correction (IPSAS 3, 2010), and other values.

However, dealing with problems from an accounting point of view as assigning a monetary value to a public asset that does not have a financial value, the economic sciences have a possible solution through environmental valuation methods. Such methods may be appropriate for the Accounting, whose discussion should be intensified nationwide since Brazil has already adopted the rules of the IPSAS - International Public Sector Accounting Standard (Costa, Travassos, Libonati, Ribeiro Filho, \& Soares, 2013; Silva \& Müller, 2013).

\subsection{Accounting Suggestion in the Public Sector to an Environmental Asset}

The recent changes occurred with the convergence of Brazil to the International Accounting Standards, recommended by the International Public Sector Accounting Standard Board (IPSASB), which created the need for measurement of results so far peculiar to the private sector (Hooper, Kearins, \& Green, 2005), and a space for debate about the increase in traditional accounting techniques has been opened by these reforms (Carnegie \& West, 2005).

Environmental assets could be treated in the broad concept of heritage assets, as a capital of cultural, historical, artistic, environmental or scientific attributes, which must be maintained for public benefit, typically in preservation context (Sayce, et al., 2009). The heritage assets are considered as environmental assets to be incorporated into the public accounts and disclosed in the balance sheets of the federative entities. Brazil has a great environmental heritage as the Amazon forest, the Foz do Iguaçu waterfalls, among other environmental assets. On the other hand, the incorporation of public assets to government has been seen as a major problem, since the international literature has discussed and some solutions have been suggested seeking an outcome about the concept and valuation of heritage assets (Christiaens, 2004).

Among the problems, a tiny promotion of accountability in the public sector is highlighted, with the disclosure of qualitative information of the environmental asset over financial reporting (West \& Carnegie, 2010). The problem is related to the final value because it promotes a mistake in the interpretation of certain features of the public sector, which would reduce the usefulness of the information, since these would be distorted by the inclusion of nonmonetary items, such as the value of existence in monetary form, especially in a non-commercial context (Sayce \& Connellan, 1998). Yet, problems about the risks of accounting professionals who would be subject to failures in the analysis of the functions and purposes of public agencies related to professional training (Carnegie \& West, 2005; Hooper, Kearins, \& Green, 2005).

Mangrove is a tangible asset of common use and it fits in the definition of the Código Civil Brasileiro (CCB) [Brazilian Civil Code], Law n. 10,406/02 in articles 100 and 103 , and it is also addressed in a Resolution of Conselho 
Federal de Contabilidade n. 1,137/08 (CFC, 2008) [Federal Accounting Council]. Lima, Silva, Borges, and MatiasPereira (2011, p. 36) state "assets of common use by people started having an accounting treatment that was not until then observed in Brazil." For Hendriksen and Van Brenda (2007), the concept of an asset is one of the fundamental elements of accounting, and other concepts, such as revenue and liabilities, derived from it. Pallot (1992) states that there is a lack of development of the concept of assets, since the cash regime predominates, which did not require recognition of many assets. However, with the implementation of the regime of competence in the public sector, the need for recognition of various assets, such as public, cultural, and environmental assets, has arised. These assets generate benefits classified as non-financial, making their value also non-financial (Pallot, 1992).
Under a possible accounting scenario for the case study, in which mangroves are considered as assets of common use, here are some suggestions of accounting procedures for the registration of an environmental asset.

In the case of historical cost, there are several measurement bases for assets to be used to different degrees and in various combinations in the financial statements. The historical cost in item 5.55a of CPC00 R1 is highlighted among these assessment bases (CPC, 2011).

The first record refers to the recognition of the part of the asset obtained by expropriation process. In the case exemplified here, part of the mangrove where ASS was installed was acquired from mills and small farmers. Due to the lack of the total amount spent with these expropriations, it was only used the term "historical cost" instead of its actual value.

Table 6

Initial Registration on Heritage Land Parcel (Mangrove ASS) Acquired By Condemnation Process

\begin{tabular}{ccc}
\hline Nature & Title & Value \\
\hline D & Environmental asset (Non-Current Assets Account) & US\$ Historical Cost \\
\hline C & Mutation Balance (Acquisition of assets) & US\$ Historical Cost \\
\hline D & Capital expenditure (Acquisition of assets) & US\$ Historical Cost \\
\hline C & Banks & US\$ Historical Cost \\
\hline
\end{tabular}

Source: Developed by the authors.

For a reassessment of the asset for environmental estimated value, with the previous record we have the asset, or asset parcel, incorporated to its acquisition value, and it is necessary to revalue it to represent its estimated environmental value. For environmental assets, both the record and the models of revaluation and update in time are little discussed, even though NBC 16:10 recognizes the need to include in the fixed asset the assets of common use received in donations or that have absorbed, or absorb public funds.

The authors Sallaberry and Vendruscolo (2012) highlight the measurement model set out in item 2 of NBC T 10.16, for which the revaluation is the adoption of market value or consensus between the parties to the assets. Failing this criterion, as in the item 37 of the same normative of the Resolution CFC n. 1,137/08, the asset value can be set based on benchmarks that consider circumstantial characteristics.

\section{Table 7}

Revaluation of the asset to the environmental estimated value (Mangrove ASS EAS)

\begin{tabular}{|c|c|c|}
\hline Nature & Title & Value \\
\hline $\mathrm{D}$ & Environmental asset (Non-Current Assets) Account) & US\$ $x x x . x x x . x x x, x x-$ Historical Cost \\
\hline $\mathrm{C}$ & Active Supervenience (Income Account) & US\$ $x x x . x x x . x x x, x x-$ Historical Cost \\
\hline
\end{tabular}

Source: Developed by the authors.

This same record will be used if the public entity wants to recognize an environmental asset of his property not yet evidenced in their heritage (Travassos, 2012).

The authors Sallaberry and Vendruscolo (2012) consider that the assets, when part of the environment, are not among the assets of common use, which refer to IPSAS 17 (2011) and NBC T 16.10. In Brazil, the Sistema Integrado da Administração Financeira (SIAFI) [Integrated System of Financial Administration of the
Federal Government] recognizes the environmental assets as common use: "2.1.1 - The common use of the people - are the rivers, seas, roads, streets, and public squares [...]" (SIAFI, 2011).

Kohama (2006) states that proprietary assets are more important to public accounting since its variations are registered and recorded in the appropriate groups according to their usual discrimination. Slomski (2001) and Kohama (2006) address the legal concept of public 
assets but refer to the accounting process only the proprietary assets. Bezerra Filho (2004) considers feasible the accounting records of assets of common use.

The Constitution of the Federative Republic of Brazil of 1988, in Articles 20 and 225, recognizes that natural resources are the Union assets considered of common use. Assets of common use by the people are inalienable, as the Law n. 10,406/02 of CCB Art. 100: "public assets of common use and special use are inalienable, while retaining their qualification, as determined by law" (CCB, 2002).

In cases of disinvestment and alienation, disinvestment is to remove that destination previously given to an asset, i.e. the disinvestment is an expression used in administrative law to name the act by which the state makes appropriable a public asset.

Table 8

Reduction by disinvestment

\begin{tabular}{cc}
\hline Nature & Title \\
\hline $\mathrm{D}$ & Proprietary assets (Lands) \\
\hline $\mathrm{C}$ & Assets of Common People Use (Mangrove ASS) \\
\hline
\end{tabular}

Source: Developed by the authors.

According to Law n. 9,636/98, the sale of assets of common use or special use would not be possible, only permitted to proprietary assets since the first would be affected with public purposes. The allocation of these assets (of common and special use) would not be definitive, with the possible reclassification to proprietary assets, as provided in art. 100 (CCB, 2002). At the federal level, the requirements for the sale of proprietary assets would be of public interest, evaluation, bidding process and legislative authorization (this last requirement is only required in the case of real estate serving the legal entities of public law).

In Brazil, the Federal Law n. 4,771/65 establishes mangroves as Permanent Preservation Areas (PPA); and Conselho Nacional de Meio Ambiente (CONAMA) [the National Environmental Council] in its Resolution n. 369/06 states that mangrove areas may not suffer suppression of vegetation or any type of intervention, except in cases of public interest. The measures adopted by laws, decrees, and resolutions of the CONAMA try to stop the advanced destruction of protected vegetation without, however, achieve precisely that goal by several factors. The removal of vegetation from a unit of permanent preservation, in the case of ASS, followed all procedures and conditions imposed by the State Law n. 11,206/95, art. $8, \S \$ 1$ and 2 (Relatório de Impacto Ambiental [RIMA], 2007).

Table 9

Disposal of asset by sale

\begin{tabular}{cc}
\hline Nature & Title \\
\hline D & Mutation Equity (Disposal of assets) \\
\hline C & Environmental Asset (Non-Current Assets) \\
\hline D & Banks \\
\hline C & Capital revenue (Disposal of assets) \\
\hline
\end{tabular}

Source: Developed by the authors.

In donation/seizure, two records are exemplified: a diminutive, the output of assets donated to a third party; and other augmentative, the receipt of a third by donation or confiscation, as provided by the Ministry of Finance of the National Treasury Secretariat, in the Manual de Contabilidade Aplicado ao Setor Público (MCASP, 2015).

Table 10

Reduction by Donation

\begin{tabular}{cc}
\hline Nature & Title \\
\hline $\mathrm{D}$ & Active Unsubstantiated (Environmental Loss) \\
\hline $\mathrm{C}$ & Assets of Common Use by People (Mangrove ASS) \\
\hline
\end{tabular}

Source: Developed by the authors. 
An asset can also be acquired through a transaction without counterprovision by the exercise of confiscation powers. Under these circumstances, the cost of the item is its fair value at the acquisition date (MCASP, 2015).

Table 11

Admission of assets by donation or confiscation

\begin{tabular}{cc}
\hline Nature & Title \\
\hline $\mathrm{D}$ & Assets of Common Use by People (Mangrove ASS) \\
\hline $\mathrm{C}$ & Active Supervenience (Income Account) \\
\hline
\end{tabular}

Source: Developed by the authors.

In case of the revaluation of the asset by suppression - impairment - the first condition for applying the impairment test is that the asset integrates patrimony, i.e., previous recognition and measurement by the accounting (Travassos, 2012). In the public sector, this prerequisite is a limitation to the test. Because of measurement difficulties, some assets are not recognized in the financial statements of public entities.

The reason for the exclusion of assets of common use and special use on public property would be the absence of an exchange value, making them difficult to be assessed in cash (Lock \& Pigatto, 2005). According to NBC T. 16.24, the public entity shall apply methods of measurement of assets and liabilities, allowing the recognition of gains and equity losses, including those resulting from recoverable value adjustments of assets (impairment adjustment) in accordance with the Basic Accounting Principles.

If the loss has occurred abnormally (environmental disaster or any other factor that is important in suppressing an environmental asset area), it is recognized the decrease in the asset by proportionality of the suppressed area in contrast to a fact amending diminutive (active insubstance).

Table 12

Impairment Environmental Discount: Loss on Suppression (ASS Mangrove - Donation)

\begin{tabular}{ccc}
\hline Nature & Title & Value \\
\hline $\mathrm{D}$ & Active insubstance (Loss of Asset) & US\$ xxx.xxx.xxx,xx \\
\hline $\mathrm{C}$ & Proprietary assets (Ipojuca Mangrove) & US\$ xxx.xxx.xxx,xx \\
\hline
\end{tabular}

Source: Developed by the authors.

According to Fernando (2009), impairment is applied in conjunction with depreciation, amortization, and depletion. In the case of 'mangrove' asset, as well as to the lands, there is no impairment loss associated with the economic useful life of the asset, since they have undetermined useful life, see Resolution CFC n. $1,136 / 08$ which deals with the depreciation, amortization, and depletion. Despite this discussion, it recognizes the possibility of public accounting incorporates environmental assets to government property, as well as the need for measurement techniques for public assets. As a contribution, this study brings a suggestion with the application of beta model in contingent valuation as a measurement technique for environmental assets.

\section{FINAL CONSIDERATIONS}

This study applied the regression model for CVM through WTP/income proportion of individuals to preserve Maracaípe mangrove. The results were consistent with the studies of Leite (2006) and Travassos (2012) who applied the method by using the beta regression model and compared their performance to traditional binary models. When analyzing the consistency of the results, it can be observed that the estimative of parameters regarding the signal and magnitude were significant and coherent with the economic theory adapted to the beta model.

The middle and upper-income groups, whose purchasing power is higher due to their incomes, showed negative signs expected in the beta model, which consists of a smaller allocation of the proportion of their incomes to the detriment of other budget priorities. The lower income group has allocated an allocation of the proportion 
of their income higher to prioritize mangrove preservation in their budget, considering timber supply, food source, biodiversity maintenance, erosion control, among other environmental benefits of mangrove.

Regarding the influence of the education and income variables in relation to the WTP of the individual, the education variable of the parameters estimated in the two models presented similar values and reflect the influence of the income variable, considering that generally higher levels of schooling (average and high) imply a higher level of income.

The use of contingent valuation by beta modeling to estimate the $\mathrm{WTP} \mu$ in contributing to mangrove preservation allowed us to estimate the value for the Ipojuca mangrove at US\$134,079,793.50; and for the damage caused by the suppression of the mangrove by the installation of the ASS at US\$61,378,155.37. This value was presented to the TCE/PE as a subsidy suggested to the supervision agents in the decision-making process by the negative externality caused to the natural resource.

The valuation of an environmental asset can also be recommended to the economic agents in the evaluation of project level and public policies, from the knowledge of environmental benefits and services, as well as the costs and externalities associated with environmental assets.
For example, the influence of an externality on pricing leads to an inferior supply to the public asset, and also the environmental services that can distort pricing to the economic agents, inducing failures to obtain these prices and incorporate them into the decision-making process.

However, the estimated final value of mangrove and of damage prompts a discussion about the implications from an accounting point of view, such as the attribution of monetary value to a public asset that does not have a financial value. Therefore, it could promote a misunderstanding in the interpretation of certain resources of the public sector and would reduce the usefulness of information and cause problems around its conceptualization and valuation of the public assets of the governmental patrimony.

The main contribution of this study is the incorporation of a flexible parametric model, the beta regression model, to estimate the WTP by CVM, serving as a contribution to the advancement in research on the method as an alternative to the accounting measurement technique for public assets. The discussion of this research reaffirms the need for further development of measurement studies related to the valuation models of environmental assets for public accounting.

\section{REFERENCES}

Araña, J. E., \& León, C. J. (2005). Flexible mixture distribution modeling of dichotomous choice contingent valuation with heterogeneity. Journal of Environmental Economics and Management, 50(1), 170-188.

Araújo, R. C. (2011). Valoração econômica do dano ambiental em inquérito civil público. Brasília, Brazil: Escola Superior do Ministério Público da União.

Armas, E. (1981). Los Recursos Naturales Del Peru. Lima, Peru: Oficina Nacional de Evaluación de Recursos Naturales, ONERN.

Arrow, K. J., Solow, R., Portney, P. R., Leamer, E. E., Radner, R., \& Shuman, E. H. (1993). Report of the NOAA panel of contingent valuation. Federal Register, 58(10), 4602-4612.

Banco Central do Brasil. (2017). Conversão de Moedas. Retrieved from http://www4.bcb.gov.br/pec/conversao/conversao.asp

Banco Central do Brasil. (2017). Taxa Referencial. Retrieved from http://www.bcb.gov.br

Banco de Dados do Estado de Pernambuco. (2010). Valor da renda média nominal mensal per capita da população. Retrieved from http://www.bde.pe.gov.br/

Benakouche, R., \& Cruz, R. S. (1994). Avaliação monetária do meio ambiente. São Paulo, Brazil: Makron Books, 198p.

Bezerra Filho, J. E. (2004). Contabilidade pública: teoria, técnica de elaboração de balanços e 300 questões. Rio de Janeiro, Brazil: Impetus.
Blakemore, F., \& Willians, A. (2008). British Tourists' Valuation of a Turkish Beach using contingent valuation and travel costs methods. Journal of Coastal Research, 25(6), 1469-1460.

Carnegie, G. D., \& West, B. P. (2005). Making Accounting accountable in the public sector. Critical Perspectives on Accounting, 16, 905-928.

Carlo, S. (1999). Meio ambiente: sua integração nos sistemas de informações estatísticas. Rio de Janeiro, Brazil: IBGE. (Textos para discussão, n. 96).

Christiaens, J. (2004). Capital Assets in Governmental Accounting Reforms: Comparing Flemish Technical Issues with International Standards. European Accounting Review, 13 (4), 743-770.

Comitê de Pronunciamentos Contábeis. (2009). Pronunciamento Técnico CPC 38, de 02 de outubro de 2009. Instrumentos Financeiros: Reconhecimento e Mensuração. Retrieved from http://www.cpc.org.br/CPC

Comitê de Pronunciamentos Contábeis. (2010). Pronunciamento Técnico CPC 04 (R1),05 de novembro de 2010. Ativos Intangíveis. Retrieved from http://www.cpc.org.br/CPC

Comitê de Pronunciamentos Contábeis. (2011). Estrutura Conceitual para Elaboração e Divulgação de Relatório ContábilFinanceiro CPC 00(R1), de 02 de dezembro de 2011. Retrieved from http://www.cpc.org.br/CPC

Comitê de Pronunciamentos Contábeis. (2016). Pronunciamento 
Técnico CPC 46, de 07 de dezembro de 2016. Mensuração do Valor Justo. Retrieved from http://www.cpc.org.br/CPC

Companhia Pernambucana Recursos Hídricos (2010). Retrieved from http://www.cprh.pe.gov.br

Conselho Federal de Contabilidade. (2008). Resolução CFC n. 1.136, 21 de novembro de 2008. Aprova a NBC T 16.9 Depreciação, Amortização e Exaustão, Brasília, DF: CFC.

Conselho Federal de Contabilidade. (2008). Resolução CFC $n$. 1.137, de 21 de novembro de 2008. Aprova a NBC T 16.10 Avaliação e Mensuração de Ativos e Passivos em Entidades do Setor Público. Brasília, DF: CFC.

Constituição da República Federativa do Brasil de 1988. Brasília, 5 de outubro de 1988.

Cooper, D. R., \& Schindler, P. S. (2003). Métodos de Pesquisa em administração (7a ed.). Porto Alegre, Brazil: Bookman.

Costa, J. I. F., Travassos, S. K. M., Libonati, J. J., Ribeiro Filho, J. F., \& Soares, V. S. (2013). Regime de competência aplicado ao setor público: análise no reconhecimento dos restos a pagar não processados e despesas de exercícios anteriores dos municípios brasileiros. BASE - Revista de Administração e Contabilidade da UNISINOS, 10(3), 240-253.

Cribari-Neto, F., \& Zeileis, A. (2010). Beta Regression in R. Journal of Statistical Software, 34(2), 1-24 Retrieved from http://www.jstatsoft.org/

Diamond, P. A., \& Hausman, J. A. (1994). Contingent Valuation: Is Some Number Better than No Number? Journal of Economic Perspectives, 8(4), 45-64.

Dutta, M., Banerjee, S., \& Husain, Z. (2007). Untapped demand for heritage: A contingent valuation study of Prinsep Ghat, Calcutta. Tourism Managment, 28, 83-95

Fernando, E. (2009). Depreciação, amortização, exaustão e imparidade. In J. F. Ribeiro Filho, J. Lopes, \& M. Pederneiras (Orgs.). Estudando a teoria da contabilidade. São Paulo, Brazil: Atlas.

Ferrari, S. L. P., \& Cribari-Neto, F. (2004). Beta regression for modeling rates and proportions. Journal of Applied Statistics, 31(7), 799-815.

Ferreira, S, \& Marques, R. (2015). Contingent valuation method applied to waste management. Resources, Conservation and Recycling, 99, 111-117.

Fischhoff, B., \& Furby, L. (1988). Measuring values: A conceptual framework for interpreting transactions with special reference to contingent valuation of visibility. Journal of Risk and Uncertainty, 1(2), 147-184.

Green, D., Jacowitz, K. E., Kahneman, D., \& McFadden, D. (1998). Referendum contingent valuation, anchoring, and willingness to pay for public goods. Resource and Energy Economics, 20(2), 85-116.

Guerra, F. G. P. Q., Santos, A. J., Sanquetta, C. R., Bittencourt, A. M., \& Almeida, A. N. (2009). Quantificação e valoração de produtos florestais não madeireiros. Floresta, 39(2), 431-439.

Haab, T. C., \& Mcconnell, K. E. (1998, May). Referendum models and economic values: theoretical, intuitive and practical bounds on willingness to pay. Land Economics, 74 (2), 216229.

Hammitt, J. K., Liu, Jin-tan, \& Liu, Jin-long. (2001). Contingent valuation of a Taiwanese wetland. Environment and
Development Economics,6(2),259-268.

Hanemann, W. M. (1984) Welfare evaluations in contingent valuation experiments with discrete responses. American Journal of Agricultural Economics, 66 (3), 332-341

Hanemann, W. M. (1989). Welfare evaluations in contingent valuation experiments with discrete data: Reply. American Journal of Agricultural Economics, 7, 1057-1061

Hausman, J. (2012). Contingent Valuation: From Dubious to Hopeless. Journal of Economic Perspectives, 26(4), 43-56.

Hendriksen, E. S., \& Van Breda, M. F. V. (2007). Teoria da contabilidade. (5a ed.). São Paulo, Brazil: Atlas.

Hooper, K., Kearins, K., \& Green, R. (2005). Knowing the price of everything and the value of nothing: accounting for heritage assets. Accounting, Auditing \& Accountability Journal, 18(3), 410-433.

Instituto Brasileiro de Geografia e Estatística. (2010). Domicílios recenseado em Cabo de Santo Agostinho. Retrieved from http:// www.cidades.ibge.gov.br/xtras/temas.php?lang=\&codmun $=260290 \&$ idtema $=1 \&$ search $=$ pernambuco $\mid$ cabo-de-santoagostinho|censo-demografico-2010:-sinopse-

Instituto Brasileiro de Geografia e Estatística. (2010). Domicílios recenseados em Ipojuca. Retrieved from http://www.cidades. ibge.gov.br/xtras/temas.php?lang=\&codmun=260720\&idtem $\mathrm{a}=1$ \&search=pernambuco|ipojuca|censo-demografico-2010:sinopse-

Instituto Nacional de Planificatión. (1980). Análisis Del Potencial Regional de Recursos Naturales em el El Peru. Tomo I, Lima: INP-DGPI-DAT (Borrador de Trabajo).

International Public Sector Accounting Standards. (2010) Accounting Policies, Changes in Accounting Estimates and Errors IPSAS 3 Retrieved from http://www.ipsas.be/ipsas-3accounting-policies-changes-in-accounting-estimates-anderrors.html

International Public Sector Accounting Standards. (2011). Property, plant and equipment IPSAS 17. Retrieved from de https://www.ifac.org/system/files/publications/files/ipsas-17property-plant-2.pdf

Kohama, H. (2006). Contabilidade pública: teoria e prática. (10a ed.). São Paulo, Brazil: Atlas.

Lei n. 6.938, de 31 agosto de 1981. Dispõe sobre a Política Nacional do Meio Ambiente, seus fins e mecanismos de formulação e aplicação, e dá outras providências. Diário Oficial da União Brasília, DF.

Lei $n$. 9.605, 12 de fevereiro de 1998. Dispõe sobre as sanções penais e administrativas derivadas de condutas e atividades lesivas ao meio ambiente, e dá outras providências. Diário Oficial da União Brasília, DF.

Lei n. 4.771 de 15 de setembro de 1965. Institui o novo Código Florestal. Diário Oficial da República Federativa do Brasil. Brasília, DF.

Lei n. 10.406, de 10 de janeiro de 2002. Institui o Código Civil. Diário Oficial da República Federativa do Brasil. Brasília, DF.

Lei $n$. 9.636, de maio de 1998. Dispõe sobre a regularização, administração, aforamento e alienação de bens imóveis de domínio da União, altera dispositivos dos Decretos-Leis nos 9.760, de 5 de setembro de 1946, e 2.398, de 21 de dezembro de 1987, regulamenta o $\$ 2$ o do art. 49 do Ato das Disposições 
Constitucionais Transitórias, e dá outras providências. Diário Oficial da União Brasília, DF.

Leite, J. C. L. (2006). Valoração Contingente através do Modelo de Regressão Beta. (Doctoral thesis). Universidade Federal de Pernambuco, Recife, PE, Brazil.

Lima, D. V., Silva, M. C., Borges, E. F., \& Matias-Pereira, J. (2011) Pesquisa empírica: uma contribuição ao tratamento Contábil dos bens de uso comum. Revista Ambiente Contábil, 3(2), 34-44.

Lock, F. N., \& Pigatto, J. A. M. (2005). A dificuldade de alinhamento entre a contabilidade pública brasileira e o Government Finance Statistics - GFS. Revista Eletrônica de Contabilidade da UFSM, 1(3), 161-181.

Malhotra, N. K. (2001). Pesquisa de Marketing: Uma Orientação Aplicada. (3a ed.). Porto Alegre, Brazil: Bookman.

Marques, J. F., \& Comune, A. E. (1987). A teoria neoclássica e a valoração ambiental. In: Romeiro, A. R., Reydon, B.P., \& Leornardi, M. L. A. Economia do meio ambiente. Campinas. Unicamp, 21-41p.

Marques, M. M., \& Freire, F. S. (2015). Mensuração de ativos culturais: uma aplicação do método do custo de viagem na Catedral de Brasília, PASOS Revista de Turismo y Patrimonio Cultural. 13(5), 1047-1066.

Martins, G. N., \& Melo, A. S. S. A. (2007, dezembro). Preservação do Parque dos Manguezais em Recife-PE: uma utilização do método de opções reais. EconomiA, Selecta, Brasília (DF), 8 (4),75-95.

Mathias, W. F., \& Gomes, J. M. (2008). Matemática Financeira. (3a ed.). São Paulo, Brazil: Atlas.

Ministério da Fazenda da Secretaria do Tesouro Nacional. (2015) Manual de Contabilidade Aplicada ao Setor Público (MCASP) (6a ed.). Aplicado à União, aos Estados, ao Distrito Federal e aos municípios. Válido a partir do exercício de 2015. Portaria Conjunta STN/SOF n ${ }^{\circ}$, de 10 de dezembro de 2014. Portaria STN no 700, de 10 de dezembro de 2014.

Morehouse, E.W. (1935). Land Valuation. In: Seligman, E. R. A. Encyclopedia of the Social Sciences. New York: Macmillan. 9, pp. 137-139.

Motta, S. R. (1997, setembro). Manual para Valoração Econômica de Recursos Ambientais. IPEA/MMA/PNUD/CNPq. Rio de Janeiro, 1-254.

NOAA U.S. Department of Commerce. (1983). Assessing the social costs of oil spills: the Amoco Cadiz case study. 144p.

NOAA U.S. Department of Commerce. (1984). The use of economic analysis in valuing natural resource damages. $154 \mathrm{p}$.

Odum, W. E., Mclvor, C.C., \& Smith, T. J. (1982). The ecology of the mangroves of South Florida: a community profile. Washington: U.S. Fish and Wildlife Service, Office of Biological Services, $144 \mathrm{p}$.

Ospina, R., \& Ferrari, S. L. P. (2012). A general class of zero-orone inflated beta regression models. Computational Statistics \& Data Analysis, 56(6), 1609-1623.

Pallot, J. (1992) Elements of theoretical framework of public sector accounting. Accounting, Auditing \& Accountability Journal, 5(1), 38-59.

Pearce, D., \& Turner, R. (1991). Economics of Natural Resources and the Environment. Land Economic, 67(2), 272-276.
Porter, S. (2004). An examination of measurement methods for valuing heritage assets using a tourism perspective. Qualitative Research in Accounting \& Management, 1(2), 68 - 92.

Relatório de Impacto Ambiental (2007). Estaleiro Atlântico Sul. Companhia Pernambucana de Recursos Hídricos. CPRH: PE.

Resolução CONAMA n. 369, de 28 de março de 2006. Dispõe sobre os casos excepcionais, de utilidade pública, interesse social ou baixo impacto ambiental, que possibilitam a intervenção ou supressão de vegetação em Área de Preservação PermanenteAPP. Brasília, DF. Diário Oficial da União n. 61, de 29 de março de 2006, Seção 1, 150-151.

R-2.12.0 for windows (32/64 bit). Retrieved from https://cran.rproject.org/bin/windows/base/old/2.12.0/

$\mathrm{R}$ version 2.12.0. Copyright (c) 2010. The R Foundation for Statistical Computing ISBN 3-900051-07-0. Platform: i386-pcmingw32/i386 (32-bit).

Sallaberry, J. D., \& Vendruscolo, M. I. (2012). Padrões internacionais de contabilidade para o setor público: análise da IPASAS 17. Administração Pública e Gestão Social, 4(1), 48-75.

Sayce, S., Britton, P., Morris, A., Sundberg, A., \& Watkin, S. D. (2009). Valuing heritage assets. Final report of a research Project: examining the case for the valuation of heritage assets. Kingston University.

Sayce, S., \& Connellan. O. (1998). Implications of valuation method for the management of property assets. Property Management, 14(4), 198-207.

Schaeffer-Novelli, Y. (1989). Perfil dos ecossistemas litorâneos brasileiros, com especial ênfase sobre o ecossistema manguezal. Publicação especial do Instituto Oceanográfico USP, 7, 1-16.

Shaeffer-Novelli, Y. (1995). Manguezal ecossistema entre a terra e o mar. São Paulo, Brazil: Caribbean Ecological Research, 64p.

Scherer, M., Sanches, M., \& Negreiros, D. H. (2009). Gestão das zonas costeiras e as políticas públicas no Brasil: um diagnóstico. Cádiz: Red IBERMAR (CYTED), 37p.

Schweitzer, J. (1990). Economics, conservation and development: a perspective from USAID. In: Vicent, J. R., Crawford, E. W., \& Hoehn, J. P. Valuing environmental benefits in developing countries: proceedings. Est. Lansing: Michigan State Univ. $1-10 \mathrm{p}$.

Serra, M. A., Garcia, E. M., Ortiz, R. A., Hasenclever, L., \& Moraes, G. I. (2004). A valoração contingente como ferramenta de economia aplicada à conservação ambiental: o caso da Estrada Parque Pantanal. Planejamento e Políticas Públicas, 27, 193-212.

Silva, N. Q. A., \& Müller, C. A. S. (2013) Nova contabilidade pública: potenciais benefícios de valoração dos heritage assets para sustentabilidade ambiental. AOS - Amazônia, Organizações e Sustentabilidade Amazon, Organizations and Sustainability, 2(2), 19-32.

Simas, A. B., Barreto-Souza, W., \& Rocha, A.V. (2010). Improved Estimators for a General Class of Beta Regression Models. Computational Statistics \& Data Analysis, 54(2), 348-366.

Sistema Integrado de Administração Financeira do Governo Federal. (2011). Manual SIAFI. Retrieved from http://manualsiafi.tesouro.fazenda.gov. br/020000/021100/021107/?searchterm=bem de uso comum do povo 
Slomski, V. (2001). Manual de Contabilidade Pública - em enfoque na Contabilidade Municipal. São Paulo: Atlas.

Solow, R. (1974). La Economia de los Recursos o los Recursos de La Economia. El Trimestre Económico. 42(166), 377-397.

Stanton, P. J., \& Stanton, P. A. (1997). Governmental accounting for heritage assets: economic, social implications. International Journal os Social Economics, 24(7/8/9), 988-1006.

Tomlinson, P. B. (1986). The botany of mangroves. New York: Cambridge University Press, 316p.

Travassos, S. K. M. (2012). Valoração econômica de dano ambiental: visão econômica contábil para o caso do Estaleiro Atlântico Sul. (Master Thesis in Accounting Sciences). Universidade Federal de Pernambuco, Recife, PE, Brazil.

Valiela, I., Bowen, J. L., \& York, O. K. (2001). Mangrove forests: one of the world's threatened major tropical environments. BioScience, 51(10), 807-815.
Wakim,V. R., Magalhães, E. A., Diane, M. V., Silva, S. P., \& Pereira, D. N. (2013). The willingness to pay by the population of Teófilo Otoni city, Minas Gerais - MG state, Brazil, for the preservation and improvement of Tiradentes Square, using Contingent Valuation Method. Journal of Environment and Pollution Research 1(1), 20-39.

Walker, S.P., \& Llewellyn, S. (2002). Accounting at home: some interdisciplinary perspectives. Accounting, Auditing \& Accountability Journal. 13(4), 425-449

West, B. P., \& Carnegie, G. D. (2010). Accounting's chaotic margins: financial reporting of the library collections of Australia's public universities, 2002-2006. Accounting, Auditing \& Accountability Journal, 23(2), 201-208.

Willis, K. (1995). Contingent valuation in a policy context: the NOAA report and its implication for the use of contingent valuation methods in policy analysis in Britain. In: Willis,K. G, \& Corkindale, J. T. (eds). Environmental Valuation: New Perspectives, CAB International, Wallingford. 